\title{
MAKING CONCEPTUAL CONNECTIONS VISIBLE TO STUDENTS IN PROFESSIONAL PROGRAMMES: THE CASE OF INITIAL TEACHER EDUCATION
}

\author{
L. Rusznyak \\ School of Education \\ University of the Witwatersrand \\ Johannesburg, South Africa \\ e-mail: lee.rusznyak@wits.ac.za
}

\section{ABSTRACT}

Degrees that prepare students for professional practice require that links be made across successive courses (for conceptual progression) and across concurrent courses (for networking and coherence). This article analyses compulsory coursework offered by five universities that participated in the Initial Teacher Education Research Project (ITERP). The analysis shows that the compulsory courses provide student teachers with opportunities to learn about different elements related to teaching: learners and learning, knowledge and curriculum, pedagogic decision-making, and the context of education in South Africa. However, the generic nature of compulsory coursework means that these topics are studied without links to students' phase and subject specialisations. Making these potential links explicit requires intentional and sustained collaboration between the lecturing teams responsible for compulsory and elective courses. This article identifies conditions for enhancing the visibility of conceptual connections to students, including strong academic leadership of programmes, and ensuring that lecturing staff understand the conceptual framework that underpins programme design.

Keywords: initial teacher education, curriculum, teaching, pre-service teacher, knowledge selection, knowledge sequencing

\section{INTRODUCTION}

Both academic and professional-orientated degrees require that students engage with conceptual knowledge that has been developed systematically over time. Due to the linear nature of time, concepts selected for formal study must be introduced to students in some predetermined sequence. An additional challenge for curriculum designers of professional degrees, like initial teacher education (ITE), is that concepts should be introduced in a sequence that enables students to draw on this knowledge to inform their developing practices with increasing sophistication (Winch 2014). While the connections between different parts of university-based coursework may be self-evident to curriculum designers and lecturers, these 
links are often far less obvious to novices who have not accessed an inner logic of the professional practice (Hoban 2005). Without access to the underlying logic informing the design of a professional programme, students may develop their knowledge and skills in piecemeal ways which could ultimately constrain their professional development.

This article identifies four elements that are essential components of all teaching interactions, and then analyses how these elements are introduced and developed in the Bachelor of Education (BEd) programmes offered by five South African Higher Education Institutions (HEIs). Despite numerous studies that point to structural, quality and logistical differences across ITE programmes (e.g. Reeves and Robinson 2014; Samuel 2010, Council on Higher Education 2010), very little is known about the progression and networking of conceptual knowledge within ITE programmes offered to South African student teachers. It is this knowledge gap that this article seeks to fill. This article draws on data from a larger comparative research project, Initial Teacher Education Research Project (ITERP) led by JET Educational Services, in conjunction with the Education Deans' Forum, the Department of Basic Education (DBE) and the Department of Higher Education and Training (DHET).

\section{FORMAL OBJECTS OF STUDY IN COURSEWORK}

Both international and South African literature reveals the tendency of student teachers initially to underestimate the cognitive demands of teaching (Joram and Gabriele 1998; Hammerness et al. 2005; Rusznyak and Walton 2014; Loughran, Berry and Mulhall 2006). At the beginning of their studies, student teachers tend to assume that teaching merely involves the acquisition and mechanical application of routine procedures. A professional degree, like the BEd, needs to provide opportunities for student teachers to both access and reconsider these assumptions if they are to deepen their understanding of the complex nature of teaching. There are universitybased courses in most (if not all) ITE programmes that are taken by all student teachers, irrespective of their phase and/or subject specialisations. These compulsory courses occupy privileged spaces in ITE curricula because the concepts they cover reflect the institution's conception of what all prospective teachers need to know before they qualify. One role of compulsory university-based coursework in ITE should thus be to enable prospective teachers to develop 'a strong and properly grounded conception of teaching' (Morrow 2007, 84). Without explicit connections to a coherent concept of teaching, coursework may seem to novices like a collection of modules without a coherent logic. Analysing the knowledge selection and sequencing decisions in compulsory coursework in ITE programmes therefore offers possibilities for understanding the potential for conceptual progression and networking 
in the ITE programme as a whole (Feiman-Nemser 1990; Cochran-Smith and Lytle 1999; Reeves and Robinson 2014; Samuel 2010).

Diverse approaches and orientations to initial teacher education have been described both internationally (e.g. Cochran-Smith and Lytle 1999; Korthagen 2004; Levine 2006) and locally (Reeves and Robinson 2014; Morrow 2007; Samuel 2008). Because of the way ITE programmes variously adopt theory-led, context-led, student-led or practice-led approaches, an analysis of course concepts using any of these frameworks would provide skewed insights, given the unevenly applied nature of the theoretical frameworks within across participating institutions. In order to identify aspects of teaching that would be relevant to all student teachers, regardless of their phase/subject specialisations, I turn to the work of three theorists who have attempted to distil the practices of teaching into its constituent elements. These elements, this study assumes, would be included in the objects of study selected for compulsory coursework across the ITE programmes offered by different universities.

The first theorist, Alexander (2000), defines teaching as follows: 'Teaching, in any setting, is the act of using method $x$ to enable [learners $]^{1}$ to learn $y^{\prime}$. Second, Darling-Hammond (1997, 294 ) regards the sine qua non ${ }^{2}$ of education to be 'whether teachers know how to make complex subjects accessible to diverse students'. Third, Morrow's (2007, 83) conception of teaching is that it is 'the professional practice of organising systematic learning'.

Four elements of teaching can be extracted from Alexander's definition. He draws together the content knowledge or skills to be learned (y); a context or setting in which teaching happens; a suitable method (x) for enabling learning, and implicit reference is made to those who are meant to learn ' $y$ '. His conception of pedagogy focuses on the practices of teaching rather than the particular nature of the teacher as a practitioner. Alexander's reference to teaching method (x), Morrow's reference to a professional practice, and Darling-Hammond's use to the phrasing 'how to' together allude to a pedagogic approach that is not randomly selected, but that needs to be thoughtfully chosen and appropriate to its purpose. Morrow's definition of teaching elaborates on the elements. The act of teaching is not merely the application of a particular method, but a conceptualisation of a process of learning that requires that the knowledge or skills to be learnt (y) are conveyed in an incremental manner to show systematisation of that knowledge. Thus, curricular knowledge about how knowledge is selected and sequenced is a fundamental part of the knowledge that all teachers need. Although neither Alexander's nor Morrow's definition differentiates between learners, DarlingHammond's conception suggests that a fundamental part of teaching is working with learner diversity. Like Alexander and Morrow, Darling-Hammond includes ‘complex subjects’ (i.e. 
systematised bodies of knowledge) to be learned as a fundamental part of teaching. Similarly, she gauges the effectiveness of a teaching action according to whether learners have gained access to the intended knowledge. Alexander's use of the word 'any' suggests that context is a variable but essential element of teaching. Morrow too draws a distinction between the formal elements of teaching (which operate in all instances of teaching and are therefore generalisable over contexts), and the material elements that 'are necessarily rooted in specific contexts' (Morrow 2007, 98). Such a distinction enables student teachers to understand how the implementation of the practice of teaching may be limited or enabled by the structural factors operating in a context, without being constrained by the notion that enabling learning can only take place under an ideal set of material conditions. The possibilities and constraints in any context is a fundamental consideration when making teaching choices. Morrow insists that a key question for those learning to teach is 'How can I organise systematic learning in this context and these conditions?' (2007, 105). Contextual and learner diversity is thus a fundamental part of what all teachers need to consider when they choose which method (x) is most appropriate to achieve the intended learning (y). Teachers need to consider the learners in their class/es and the possibilities in the school context in which they practice.

The elements essential to teaching that I extract deductively from these three definitions therefore include:

- $\quad$ The teacher ${ }^{3}$

- The knowledge to be taught/learnt

- $\quad$ Learners

- $\quad$ Pedagogy

- The context/s in which teaching is situated

If student teachers are to understand teaching as a complex but coherent practice, they need to learn about each of these elements individually, and in relation to one another (Winch 2014). What constitutes appropriate action in professional practice depends on a conceptuallyinformed judgment that considers all these elements of teaching simultaneously. The development of professional practice thus requires that student teachers learn to generate rational, justifiable and principled responses within the complexity of classroom life based on a deep understanding of theory. However, these responses need to be embodied in relation to learners, curricular imperatives, and contextual variables (Shalem 2014; Guile 2014). 


\section{THE GROUNDS OF KNOWLEDGE SELECTION FOR COMPULSORY COURSES}

Curriculum designers identify concepts for formal study on the grounds that they support the development of professional practices and would best be learnt through university-based coursework (rather than classroom-based experience). The concepts included in compulsory coursework can be derived from theoretical disciplines, from principles arising from the practical knowledge of teachers, and studies of the current contextual realities of schooling in South Africa. In the section that follows, the potential contribution of each of these kinds of knowledge to the professional preparation of teachers will be briefly considered.

Theoretical knowledge included in compulsory education courses introduces student teachers to bodies of formal knowledge that provide them access to the best-known insights on educational matters. This knowledge offers non-intuitive insights on practice and is primarily derived from the disciplines of psychology, sociology, and philosophy. These insights cannot be acquired through personal reflection on classroom-based observations or experience and therefore need to be formally taught (Hirst in Hirst and Carr 2005; Shay 2013). Theoretical knowledge plays a crucial role in supporting prospective teachers in developing a specialist understanding of teaching as a complex knowledge-based practice, and ultimately provides a basis for rational and conceptually-informed professional judgments (Shalem 2014).

Principles of teaching practices and classroom-based procedures are also often included in compulsory coursework. This practical knowledge introduces student teachers to principles derived from the experiences, techniques and insights of expert practitioners. While students may potentially accumulate this practical knowledge through classroom observations and reflections on their teaching experiences, individual experiential learning tends to be highly idiosyncratic. Leaving the accumulation of practical knowledge to personal classroom experiences means that there will invariably be gaps in students' knowledge which may unnecessarily constrain the development of their teaching practices (Flores 2006). The inclusion of aspects of practical knowledge in university-based coursework ensures that all students have access to a common set of principles for practice.

\section{CONTEXT OF THIS STUDY}

There are several reports pointing to variation between the ITE programmes offered by different South African universities. This is not surprising, given that the legacy of Apartheid resulted in a highly fragmented teacher education sector, with divisions along racial and regional lines. In an attempt to consolidate the sector, teacher education was relocated to the higher education sector in 2000. To promote greater convergence between ITE programmes, a recently revised 
policy, the Minimum Requirements for Teacher Education Qualifications (henceforth, MRTEQ), requires that all ITE programmes have a specified 'knowledge mix' of disciplinary learning (which includes theoretical studies in education, as well as subject content knowledge), pedagogical learning (which emerges from the practical knowledge of teachers), practical learning (individually acquired knowledge acquired from observing, analysing and reflecting on one's own teaching and the teaching of others), situational learning (learning about the diverse contexts in which teaching happens), and foundational learning (the generic competences that might be useful in the work that teachers do). The 'knowledge mix' specified for each programme does not (nor should it) specify which concepts in each category are to be learnt or when these concepts should be learned. This knowledge selection and sequencing decisions are left to the teacher educators who conceptualise and design coherent ITE programmes. HEIs have finished recurricularising their ITE programmes in light of MRTEQ, and are now redesigning coursework as their newly-accredited programmes roll out. It is thus an opportune time to consider how concepts of knowledge, learners, contexts and pedagogy can be systematically developed and explicitly connected across coursework to strengthen the conceptual coherence of the programme.

\section{METHODOLOGY}

This article reports on a qualitative analysis of the compulsory courses that offer student teachers perspectives on education, teaching and learning (variously named education theory, education studies, curriculum studies and/or professional studies), offered by five South African universities to student teachers registered for a 4-year BEd programme. Ethical clearance for the study was obtained from the DHET, as well as from the Ethics committees of each participating HEI. The five universities were purposively selected to reflect a diverse range of histories and contexts of HEIs in South Africa. The institutions reflect some diversity according to geographical location (urban/rural), their language of instruction (Afrikaans/ English), merger history (some experienced mergers of former teacher training colleges or technikons with universities), as well as resourcing legacies. The participating universities will be referred to by an assigned letter as follows:

Table 1: Brief descriptions of the participating universities in the ITERP study

\begin{tabular}{|l|l|}
\hline A & $\begin{array}{l}\text { Formerly-advantaged English-speaking university, located in an urban context. Initial teacher education is } \\
\text { offered in full-time contact mode. }\end{array}$ \\
\hline B & $\begin{array}{l}\text { University offering teacher education on multiple campus sites. Teacher education programme under } \\
\text { review is located in a formerly-advantaged Afrikaans-speaking campus. Initial teacher education is offered }\end{array}$ \\
\hline
\end{tabular}




\begin{tabular}{|l|l|}
\hline & through partial distance learning and full-time contact modes. \\
\hline C & University offering initial teacher education to students through distance learning. \\
\hline D & $\begin{array}{l}\text { Formerly-disadvantaged university located in a rural context. Initial teacher education is offered in full-time } \\
\text { contact mode. }\end{array}$ \\
\hline E & $\begin{array}{l}\text { Technical university offering teacher education on multiple campus sites. Initial teacher education is } \\
\text { offered in full-time contact mode. }\end{array}$ \\
\hline
\end{tabular}

The primary data used for this study come from the official documents relating to the BEd programme structure/s, course descriptions in official syllabus books, course outlines and study guides (where available) of all the compulsory education courses taken by BEd students across different phase/subject specialisations. A secondary source of data was from interviews with the BEd programme coordinators and lecturers of the compulsory education/pedagogy modules. The structure of the BEd degree/s offered by each institution was examined to identify compulsory courses that all students complete, irrespective of different phase/subject specialisations. The main concepts taught in these courses were identified from the programme/course documentation provided, and confirmed during lecturer interviews. Using the four elements that exist in all teaching interactions as categories, concepts were then classified according to the extent to which they contributed to students' understanding of the learners they teach, what they teach (curriculum and knowledge), how they teach (pedagogy), as well as the setting/s in which they teach (contexts). It then became possible to identify similarities and differences in terms of knowledge selection and sequencing decisions in relation to each of the four elements.

There are inherent limitations in the methodology and data sets used. First, the documents analysed provide access to the officially-espoused curriculum. Other iterations of the curriculum (such as the enacted curriculum, the acquired curriculum, the hidden curriculum and the assessed curriculum) are not included in this analysis. Secondly, the syllabus descriptions and course/module outlines provide an indication of main concepts covered, but do not always provide a nuanced account of each lecture. It is also not possible to report on the extent to which any individual lecture in such coursework refers to concepts developed elsewhere. Although these limitations could be somewhat mitigated by triangulation from the interview data, the research does not have transcripts of every lecture. For these reasons, the findings of this study are both partial and provisional. Thirdly, in all institutions, each BEd degree contains numerous elective options, first in terms of the phase for which student teachers are being prepared, and secondly the teaching subject/s students can choose as a specialisation. A consideration of all of these elective courses falls beyond the scope of this study.

\section{FINDINGS}


Concepts relating to the four elements of teaching (identified as knowledge; pedagogy; learners and contexts) are formal objects of study in the compulsory coursework of all five BEd programmes analysed. Table 2 provides an overall summary of the year/s in which each element is introduced and developed within every BEd programme analysed. It can be seen from the table that there is considerable alignment between the concepts covered: all teachers qualifying from these institutions will have studied modules on human development, inclusive education, the education law in South Africa, the role of schooling in society, the nature of curriculum, and aspects of pedagogy. These all exist as objects of study in compulsory coursework, albeit in different sequences, to varied depth, and as the analysis that follows will show, from different perspectives.

Table 2: Summary of the years of study in which concepts are taught to BEd students in compulsory courses in 5 participating institutions

\begin{tabular}{|c|c|c|c|c|c|c|}
\hline $\begin{array}{l}\text { Elements of } \\
\text { all teaching } \\
\text { interactions }\end{array}$ & Concepts & 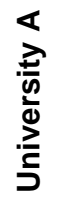 & 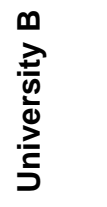 & 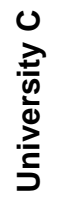 & 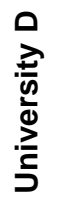 & 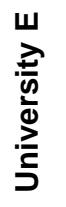 \\
\hline \multirow{3}{*}{$\begin{array}{l}\text { Knowledge } \\
\text { and } \\
\text { curriculum }\end{array}$} & Selection and sequencing of knowledge & $1 ; 2$ & 1 & - & 3 & 3 \\
\hline & Familiarity with current curriculum & - & 1 & - & 2 & 1 \\
\hline & Curriculum contestation and change & 2 & 1 & - & - & - \\
\hline \multirow[t]{2}{*}{ Learners } & $\begin{array}{l}\text { Human development theory and stages of how } \\
\text { children learn }\end{array}$ & 1 & $2 ; 3$ & $1 ; 2$ & 2 & $1 ; 3$ \\
\hline & Learner diversity and 'barriers to learning' & 3 & $1 ; 2 ; 3$ & 4 & $1 ; 4$ & $2 ; 4$ \\
\hline \multirow{6}{*}{$\begin{array}{l}\text { General } \\
\text { Pedagogy }\end{array}$} & Pedagogy with respect to learner need & 3 & 3 & $3 ; 4$ & 4 & $2 ; 4$ \\
\hline & Lesson planning & 1 & 1 & 1 & 1 & 1 \\
\hline & Use and design of learning materials & - & 3 & - & 2 & 1 \\
\hline & Classroom management & 1 & $2 ; 3$ & 2 & - & 2 \\
\hline & Teaching and learning strategies & - & $2 ; 3$ & - & 2 & 4 \\
\hline & Assessment & 4 & $2 ; 4$ & - & 3 & 4 \\
\hline \multirow[t]{7}{*}{ Context } & Environmental concerns & - & 3 & - & 4 & - \\
\hline & History of education in SA context & 2 & $1 ; 4$ & - & - & $1 ; 3$ \\
\hline & Role of schools in society & $1 ; 2$ & 1 & 2 & 1 & 1 \\
\hline & Education and the law & 4 & 4 & 3 & $3 ; 4$ & 3 \\
\hline & School and administrative routines & 4 & 1 & 1 & 3 & 4 \\
\hline & Schools as institutions; school management & 4 & 4 & 4 & $3 ; 4$ & 3 \\
\hline & Role of teacher unions & 4 & - & - & - & - \\
\hline \multirow[t]{4}{*}{ Teacher } & Ethics in education & 4 & 2 & 3 & - & - \\
\hline & Teacher identity & $1 ; 4$ & 1 & 1 & - & 1 \\
\hline & Conception of teaching and professionalism & $1 ; 4$ & 1 & - & - & 3 \\
\hline & Knowledge bases of teaching practices & $1 ; 3$ & - & - & - & 3 \\
\hline
\end{tabular}

I now turn my attention from general trends about sequencing and networking to consider each of the four elements of teaching in turn. 


\section{Knowledge, curriculum and curricular change}

Curriculum knowledge is demarcated as a discrete object of study in compulsory education courses from Universities A, B, D and E, albeit from different perspectives. Universities B, D and E introduce curriculum studies as a form of practical knowledge, with compulsory modules introducing students to the ways in which teachers work with curriculum documents in their day-to-day work of devising units of lessons. In this approach, students are introduced to the current iteration of the school curriculum. This approach positions them as future practitioners and acquaints them with the expectations of the current national curriculum generally. This general introduction in students' first or second year presumably sets a foundation for a more focused study of the current curriculum in different subject/grades within courses linked to students' specialisation. While an exclusive focus on the current curriculum may prepare students for immediate classroom practice, it is possible that as a result, students' developing teacher identities are inadvertently attached to a particular iteration of the curriculum. This is unproblematic so long as the curriculum remains unchanged, but may potentially lead to professional destabilisation when curriculum change inevitably comes. To develop a generalised understanding of curriculum change, students need to understand that knowledge selection and sequencing decisions are negotiated between the civil society, government officials, practicing teachers, and subject experts. Universities A, B, D and E offer students some coursework on the development of curricula, and alert them to the contestations over knowledge selection decisions, and how these processes can be informed, in part, by the engagement and submissions of teachers in consultation processes.

Table 3: Comparison of main concepts related to knowledge and curriculum studied in each year of study across five BEd programmes

\begin{tabular}{|l|l|l|l|l|}
\hline & Year 1 & Year 2 & Year 3 & Year 4 \\
\hline A & $\begin{array}{l}\text { Selection and sequencing of } \\
\text { subject matter knowledge in } \\
\text { teaching }\end{array}$ & $\begin{array}{l}\text { Curriculum changes over } \\
\text { the historical changes of } \\
\text { education in SA }\end{array}$ & - & - \\
\hline B & $\begin{array}{l}\text { Curriculum change in SA and } \\
\text { philosophical underpinnings of } \\
\text { education in SA context; } \\
\text { teacher as a dynamic agent of } \\
\text { curriculum development }\end{array}$ & - & - & - \\
\hline C & - & - & - & - \\
\hline D & - & - & $\begin{array}{l}\text { Curriculum theory and } \\
\text { development }\end{array}$ & - \\
\hline E & $\begin{array}{l}\text { Knowledge selection and } \\
\text { sequencing; working with } \\
\text { curriculum documentation }\end{array}$ & - & $\begin{array}{l}\text { Overt, covert and hidden } \\
\text { curriculum; values in } \\
\text { current curriculum }\end{array}$ & - \\
\hline
\end{tabular}

Universities A and B require students to study curriculum change over time through one of two disciplinary perspectives, namely the history of education in South African (University A) and 
the shifts in the philosophical ideologies that have influenced South African politics (University B). Students study how curriculum documents reflect both the imperatives of subject matter knowledge and the changing priorities and philosophies during different periods in South Africa's history. In both cases, theoretical insights are brought to bear on particular iterations of curricula. Student teachers are thus provided with the conceptual tools to understand the political agendas that have influenced recurricularisation processes. This knowledge potentially provides a more generalised perspective with which they can understand the current curriculum as transitory, contested, and politically situated.

\section{Learner similarities and differences}

The analysis of the data reveals how modules develop knowledge about learners on two levels, namely the ways in which learners in a class may be similar, and the ways in which they may be different. All institutions participating in this study require that student teachers complete studies in models of child and adolescent development, and this suggests a shared view that a psychological perspective on patterns of child development is important for all prospective teachers. Student teachers' attention is drawn to the general patterns that exist in the cognitive, moral, and social development of children of a similar age. There is little evidence in the available data to suggest that compulsory coursework engages with practice-based implications for how teachers draw on patterns of human development to inform pedagogic decision making. This absence implies that links are either absent, are attended to in a generic way, or that they are located in phase-specific coursework that considers how learning is best organised for children of a particular age range. In the case of the latter two, explicit links require intentional collaboration between lecturers of compulsory and specialisation courses.

All participating institutions offer modules that enable student teachers to become aware of learner differences that may exist within a class. Some programmes (e.g. those offered by Universities A and E) use a sociological lens for students to understand that identity markers (such as gender, race, dis/ability) are socially constructed and maintained by societal and institutional structures. Most programmes include some coursework that seeks to enable student teachers to understand the difficulties with learning that can be experienced by some learners. Some institutions draw on the framework of White Paper Six (Department of Education 2001) to identify the particular intrinsic and extrinsic 'barriers to learning' experienced by a learner that have the potential to impede on his/her classroom participation. In this way, learner difference is emphasised.

One notable difference across institutions can be seen in the sequence in which students 
learn about learner commonality and learner difference. In two of the programmes studied (Universities A and E), understanding how learners in a class may be similar (through general theories of cognitive, social child development) is introduced to student teachers before aspects of socially-constructed differences and diverse learner needs is introduced in the third or fourth year of study. In other words, knowledge of learner diversity is complexified only after students understand the ways in which learners may be similar. In Universities B and D, however, student teachers' attention is drawn initially to aspects of learner difference: to the identification of barriers to learning and a range of tips to support learners with additional support needs. Learning general patterns of child development and the work of influential learning theorists (which students' attention to similarities in learner development) comes later. By having their attention drawn first to learner differences and then to learner similarities, students are alerted early to the individuality of learners and possibly to their unique learning needs. However, this may also lead to students becoming overwhelmed at the challenges of catering for every child, with vastly different learning needs from their classmates.

Table 4: Comparison of main concepts related to learners studied in each year of study across five BEd programmes

\begin{tabular}{|c|c|c|c|c|}
\hline & Year 1 & Year 2 & Year 3 & Year 4 \\
\hline A & $\begin{array}{l}\text { How children learn; stage } \\
\text { theories of child } \\
\text { development }\end{array}$ & - & $\begin{array}{l}\text { Emotional and social } \\
\text { development of learners } \\
\text { diversity social } \\
\text { constructions of gender } \\
\text { and race }\end{array}$ & - \\
\hline$B$ & $\begin{array}{l}\text { Identifying and supporting } \\
\text { barriers to learning in } \\
\text { classroom contexts }\end{array}$ & $\begin{array}{l}\text { Human development theory } \\
\text { (child to late adolescent); } \\
\text { Physical, neurological; } \\
\text { Emotional, behavioural and } \\
\text { social barriers to learning and } \\
\text { intellectual barriers to } \\
\text { learning }\end{array}$ & $\begin{array}{l}\text { Variables that influence } \\
\text { learner performance, such } \\
\text { as prior knowledge; } \\
\text { environment; motivation; } \\
\text { cognitive reflection and } \\
\text { behaviour }\end{array}$ & - \\
\hline $\mathrm{C}$ & $\begin{array}{l}\text { The learning child; } \\
\text { relationships that support } \\
\text { learning: learner; teacher; } \\
\text { school; family; giftedness } \\
\text { and learning }\end{array}$ & $\begin{array}{l}\text { Child development: physical, } \\
\text { cognitive, affective, social; } \\
\text { relationships }\end{array}$ & - & $\begin{array}{l}\text { Multicultural } \\
\text { education }\end{array}$ \\
\hline $\mathrm{D}$ & - & $\begin{array}{l}\text { Human development and } \\
\text { learning }\end{array}$ & - & - \\
\hline $\mathrm{E}$ & $\begin{array}{l}\text { Human developmental } \\
\text { domains } \\
\text { Developmental and } \\
\text { learning theories }\end{array}$ & $\begin{array}{l}\text { Extrinsic and medical barriers } \\
\text { to learning }\end{array}$ & $\begin{array}{l}\text { Cognitive; Emotional; } \\
\text { Social and moral } \\
\text { development of children }\end{array}$ & $\begin{array}{l}\text { Diversity and } \\
\text { human rights, } \\
\text { race, class } \\
\text { and sexual } \\
\text { orientation }\end{array}$ \\
\hline
\end{tabular}

From the outset, first year students in Universities A and C learn about generalised patterns of human development, where learner similarities are the initial focus. Knowledge about learner diversity is introduced subsequently. In contrast, students from University B focus initially on learner diversity that exists in South African classrooms, and the barriers to learning that 
individuals may experience. It is not productive for prospective teachers to over- or underestimate the extent to which teachers work with learner diversity. Either of these can undermine attempts to produce teachers who are responsive to (yet not overwhelmed by) the diverse learning needs in the classes they teach.

\section{Pedagogy: The basis on which teaching decisions are made}

General pedagogical knowledge relates to those aspects of teaching that transcend subject concerns. An important part of this analysis is the parts of pedagogy that are considered by different HEIs to be general, and are thus located in compulsory courses, and those parts that are considered to be subject/phase specific.

\section{Pedagogy and the role of content knowledge}

Universities A and E include study of the role that content knowledge plays in determining appropriate teaching decisions. While this aspect may be included in the subject-specific pedagogy courses of other institutions, for these two institutions, it is also a discrete object of study in compulsory education courses. It is noteworthy that both universities include this knowledge in students' first year of study, presumably to provide a framework for observing connections between education studies, content and pedagogy courses.

In Universities A and C, learning about teaching and learning strategies and materials design is located exclusively in subject- and phase-specific pedagogy modules. This suggests a central role of pedagogical content knowledge (PCK) in informing the curriculum design, in which the appropriateness of a pedagogic approach is not generalisable but is logically derived from a subject/phase specialisation.

By contrast, Universities B, D and E introduce their students to a general range of teaching strategies and principles for general principles of materials development, in addition to courses offering subject-specific pedagogy. The implication here is that there is a shift between presenting teaching and learning strategies as general and as specialised to subject areas. It is noteworthy that in University B and D, the general modules on teaching and learning strategies are located in the second year of study, prior to the commencement of subject-specific pedagogy.

General principles for assessment are offered by Universities A, B, D and E in compulsory coursework, and are notably located in either the third or fourth year of study. This suggests a common understanding that in order to engage with principles of assessment meaningfully, students need to have acquired a significant level of content and pedagogic knowledge. The 
available data does not show whether the general principles of assessment taught are then explicitly revisited within subject-specific modules.

Table 5: Comparison of main concepts related to pedagogy studied in each year of study across five BEd programmes

\begin{tabular}{|l|l|l|l|l|}
\hline & Year 1 & Year 2 & Year 3 & Year 4 \\
\hline A & $\begin{array}{l}\text { Organising knowledge and } \\
\text { organising learners: teacher's } \\
\text { work in making knowledge } \\
\text { accessible to all learners } \\
\text { Lesson analysis and planning }\end{array}$ & - & - & $\begin{array}{l}\text { Principles of } \\
\text { assessment }\end{array}$ \\
\hline B & Lesson planning & $\begin{array}{l}\text { Teaching and } \\
\text { learning strategies }\end{array}$ & $\begin{array}{l}\text { Principles for } \\
\text { materials } \\
\text { development }\end{array}$ & $\begin{array}{l}\text { Principles of } \\
\text { assessment }\end{array}$ \\
\hline C & - & - & - & - \\
\hline D & - & $\begin{array}{l}\text { Educational media } \\
\text { Teaching and } \\
\text { learning strategies }\end{array}$ & $\begin{array}{l}\text { Assessment in } \\
\text { Education }\end{array}$ & - \\
\hline E & $\begin{array}{l}\text { Media and chalkboard work } \\
\text { Lesson planning }\end{array}$ & $\begin{array}{l}\text { Classroom } \\
\text { management } \\
\text { Discipline and } \\
\text { learner behaviour }\end{array}$ & - & $\begin{array}{l}\text { Principles of } \\
\text { assessment } \\
\text { Teaching and } \\
\text { learning strategies }\end{array}$ \\
\hline
\end{tabular}

\section{Pedagogy and the role of learner support}

All programmes in the study include inclusive education as an object of study in its own right. Some (e.g. University A and D) consider inclusive education primarily through a sociological lens. Students are alerted to the exclusionary structures and marginalising practices that are prevalent in schooling institutions and classrooms. This approach seeks to empower student teachers to identify, resist and dismantle exclusionary practices in the hope of achieving a more socially just education system. Others (e.g. University B and E) focus on the specific learning needs of particular learners, drawing primarily on insights obtained from educational psychology. Such coursework is intended to prepare student teachers to identify and remove (where possible) the intrinsic and extrinsic barriers that make learning difficult for particular learners.

Table 6: Comparison of main concepts related to pedagogy with respect to learner diversity studied in each year of study across five BEd programmes

\begin{tabular}{|l|l|l|l|l|}
\hline & Year 1 & Year 2 & Year 3 & Year 4 \\
\hline A & $\begin{array}{l}\text { Teacher's role in } \\
\text { working to make } \\
\text { knowledge } \\
\text { accessible to all } \\
\text { learners }\end{array}$ & - & $\begin{array}{l}\text { Difference and diversity; social } \\
\text { justice and epistemological } \\
\text { access to education; Inclusive } \\
\text { pedagogies; planning' learning } \\
\text { for all' in ordinary classrooms }\end{array}$ & - \\
\hline B & $\begin{array}{l}\text { Identification of } \\
\text { barriers to learning } \\
\text { and provision of } \\
\text { support }\end{array}$ & $\begin{array}{l}\text { Development of health } \\
\text { promoting schools; } \\
\text { Psycho-social } \\
\text { dynamics of a } \\
\text { classroom; }\end{array}$ & $\begin{array}{l}\text { Accommodation of learners with } \\
\text { specific barriers to learning in } \\
\text { different classroom contexts; } \\
\text { Implement the SIAS-process; } \\
\text { collaboration with parents and }\end{array}$ & - \\
\hline
\end{tabular}




\begin{tabular}{|l|l|l|l|l|}
\hline & & $\begin{array}{l}\text { Supportive classroom } \\
\text { environments }\end{array}$ & $\begin{array}{l}\text { Other professionals to support } \\
\text { learners }\end{array}$ & \\
\hline C & - & - & - & $\begin{array}{l}\text { Multicultural } \\
\text { education; } \\
\text { multicultural } \\
\text { methodology and } \\
\text { managing } \\
\text { multicultural schools } \\
\text { and classrooms }\end{array}$ \\
\hline D & - & & $\begin{array}{l}\text { Inclusive education } \\
\text { (no further detail } \\
\text { available) }\end{array}$ \\
\hline E & - & - & - & $\begin{array}{l}\text { Inclusive education } \\
\text { (no further detail } \\
\text { available) }\end{array}$ \\
\hline
\end{tabular}

The focus of inclusive education coursework requires that a teacher considers the appropriateness of his/her pedagogic responses to learner diversity. In some coursework, teacher response to learner diversity is presented as a repertoire of targeted, 'prescribed' interventions for learners in response to particular diagnoses (e.g. ADHD), or barriers to learning (this is done at Universities B and C). Approaches that advocate the application of prescribed interventions to support learners with particular barriers to learning can be taught generically, with little or no connection to phase- or subject-specific coursework. An alternative approach advocates forms of graded support built into each lesson design, with the view that all learners should receive sufficient support, which enables them to engage with the intended content to be learnt. A pedagogic response model of learner support (used by University A) is more deeply connected to teachers’ pedagogic content knowledge. Although general principles of inclusive pedagogies may be presented in compulsory coursework, the pedagogic reasoning would need embodiment in subject/phase specific coursework. The success of the latter approach demands more collaboration between lecturers of inclusive education and those who teach subject- and phase-specific coursework.

\section{The contexts in which teaching happens}

Given the extreme contextual diversity in South African schools, it is difficult to prepare student teachers for particular contextual settings through formal instruction in compulsory courses, unless there is a strong probability that most, if not all, students will obtain teaching posts in similar contexts. Although several universities include focus on the state of South African schooling and the inequalities therein, very little localised contextual knowledge is found in the compulsory coursework offered. Aspects of the contextual realities of the majority of South African schools are introduced through numerous elective and other compulsory modules (including, for example, language for learners whose mother tongue is different from the 
language of teaching and learning, the importance of learners' prior knowledge, the illegitimacy and continued prevalence of corporal punishment in schools, and attention to the diverse contexts of schooling during practicum learning). The analysis of the data shows that compulsory coursework tends to focus generally on the current state of schooling in the South African context, and the legislative and institutional milieu in which teaching is located.

Table 7: Comparison of main concepts related to the contexts of schooling in South Africa studied in each year of study across five BEd programmes

\begin{tabular}{|c|c|c|c|c|}
\hline & Year 1 & Year 2 & Year 3 & Year 4 \\
\hline$A$ & $\begin{array}{l}\text { Role of school in } \\
\text { society; structural } \\
\text { functionalism; } \\
\text { reproduction and } \\
\text { teacher agency }\end{array}$ & - & $\begin{array}{l}\text { Dismantling exclusionary and } \\
\text { marginalising school and } \\
\text { classroom practices }\end{array}$ & $\begin{array}{l}\text { Education and the law; } \\
\text { Teachers' and learners' rights } \\
\text { and responsibilities; codes of } \\
\text { conduct; Teacher identity } \\
\text { pre/post 1994; } \\
\text { professionalisation and } \\
\text { teacher unions; Organisation, } \\
\text { administration and } \\
\text { management of schools }\end{array}$ \\
\hline$B$ & $\begin{array}{l}\text { Major school routines } \\
\text { and administrative } \\
\text { activities }\end{array}$ & - & $\begin{array}{l}\text { Education Management } \\
\text { Educational systems; } \\
\text { Management tasks of educators; } \\
\text { Leadership in education; } \\
\text { classroom management }\end{array}$ & $\begin{array}{l}\text { Educational Law; Code of } \\
\text { ethics; Bill of rights; Learner } \\
\text { discipline and the law; Labour } \\
\text { law in SA; Current debates in } \\
\text { educational systems }\end{array}$ \\
\hline$C$ & - & - & $\begin{array}{l}\text { Educational Law and Professional } \\
\text { Ethics education: Educational law; } \\
\text { labour relations; roles, rights and } \\
\text { responsibilities of professional } \\
\text { teachers }\end{array}$ & $\begin{array}{l}\text { Schooling within the SA's } \\
\text { education system and other } \\
\text { critical issues }\end{array}$ \\
\hline $\mathrm{D}$ & - & - & $\begin{array}{l}\text { School leadership and } \\
\text { management Society, educational } \\
\text { law and school governance }\end{array}$ & $\begin{array}{l}\text { Management of school } \\
\text { systems and extra-curricular } \\
\text { activities }\end{array}$ \\
\hline$E$ & $\begin{array}{l}\text { Can schools change } \\
\text { society or do they } \\
\text { perpetuate the status } \\
\text { quo? Different } \\
\text { societies today (the } \\
\text { privileged and the } \\
\text { disadvantaged): } \\
\text { effect on education } \\
\text { and schools }\end{array}$ & - & $\begin{array}{l}\text { Discipline and authority in } \\
\text { Schools; Education Management: } \\
\text { Education Law (e.g. Constitution; } \\
\text { SA Schools Act; Bill of Rights) } \\
\text { South African Council for } \\
\text { Educators; School Governance }\end{array}$ & $\begin{array}{l}\text { Duties of management and } \\
\text { educators }\end{array}$ \\
\hline
\end{tabular}

The analysis of the data shows two different kinds of learning associated with modules relating to the contexts of schooling in South Africa. All five programmes offer compulsory modules where students are introduced to existing school and management structures. They are briefed about the expectations schools will have of them as newly-qualified teachers in terms of school routines, administrative processes and responsibilities. Such coursework potentially smooths the transition prospective teachers make from being university students to newly-qualified teachers. Although most universities locate these topics in the latter part of students' studies, the administrative duties of a teacher is one of the first things that student teachers from University B learn. Universities B and D include more modules on the context of schooling in South African and the effective management of schools than other institutions, and education 
management and education law form a stand-alone module in the other universities.

Modules offered to students in Universities A and E equip students with the conceptual tools for thinking about the roles of education and schooling in society from a sociological perspective. The nature of the inequalities and challenges facing the provision of quality education for all South African learners can be theoretically interrogated. Among the things that students will be equipped to critically engage with are the role that structures play in maintaining the status quo, as well as the role that teachers can play as agents of change. ${ }^{4}$ The concept of teacher agency extends learning on inclusion and exclusion, where students are alerted to potentially marginalising school structures, and unjust social or educational practices. The concept of teachers as agents of change potentially creates a tension between newlyqualified teachers and staff at the schools at which they find employment, given that these teachers need to work productively within existing school structures. However, in enabling them to acquire critical sensibilities in relation to unjust or ineffective educational practices, conditions of possibility are established for teachers to recognise ineffective or unjust teaching practices within their schools, and to resist them. In this way, student teachers are alerted to teaching as a moral practice, which seeks educational justice for all.

\section{DISCUSSION}

While a nuanced understanding of each element of teaching on its own terms is crucial for the development of conceptually-informed practice, these elements need explicitly to be brought into meaningful relation with one another if universities are to offer students coherent professional programmes (Winch 2014). The findings of this analysis have shown that four elements central to teaching are included in the compulsory coursework of all five programmes analysed. Furthermore, some are revisited and developed from different perspectives and at different levels of generality over different years of study.

The analysis of the data suggests three ways in which students' knowledge of the identified elements of teaching may be connected across different parts of an ITE programme. First, numerous modules (e.g. those related to the use and design of teaching and learning materials) appear to be stand-alone modules, as they are not revisited within the compulsory stream of coursework. It is conceivable that concepts from these modules are further developed within in phase- or subject-specific coursework. When teaching is presented as a generic practice that is governed by principles that stand outside of the demands of what is to be taught, there is less need for connections to be made between compulsory and elective (subjectspecific) coursework. However, if the appropriateness of pedagogic choices in teaching is 
understood as being deeply connected to what is being taught, lecturer collaboration across compulsory and elective coursework becomes imperative for conceptualising programmatic coherence.

Secondly, in numerous cases, the same concept is revisited in courses offered in different years of study. In some cases, the same conceptual object of study is viewed from the perspective of two different elements of teaching identified. For example, student teachers at Universities B and E study class management and discipline both as practical knowledge (in a pedagogy-focused module) and also as contextual knowledge (as part of the legislative policies governing the management of South African schools). Where a conceptual framework is introduced early in the programme, it potentially provides a common foundation on which specialisation courses can build on deductively. In all five programmes, for example, lesson planning is an object of study for first year students, and this can presumably be developed further in elective modules. Alternatively, a theoretical framework might be introduced in the latter parts of the programme, with the intention to abstract generalisable principles governing teaching practices introduced in specialisation (elective) modules. This may form part of the reason why modules on assessment are located in the third or fourth year of study in four of the programmes analysed. It is possible that these potential connections may be explicitly made in the coursework of some subject/phase specialisations, but not in others.

Thirdly, it may be that connections are made in the expectations and assessment rubrics that universities use with student teachers in their practicum sessions (Rusznyak and Bertram 2015). Curriculum coherence is advanced when a coherent conception of teaching informs curriculum design is made visible to students, and is aligned with the grounds on which student competence in teaching practice is assessed.

When concepts are studied in isolation, and not with explicit links to any other part of the ITE programme, students are left to figure out the relevance of these concepts to their developing teaching practices independently. Seeing relations between the 'parts' and the 'whole' is exceedingly complex for novices who are just beginning to access the internal logic of a practice (Shalem and Slonimsky 1999). The expectation that students will figure out the connections themselves potentially leads to unnecessary frustration (Hoban 2005). Through a formal study of the nature of teaching as a concept in its own right, compulsory courses can more explicitly be brought into relation with the different concepts studied, and provide students with access to the logic underpinning the design of their ITE curriculum.

Unless the relationships between various components of ITE programmes are explicitly considered from the outset, there exists the potential for the design of compulsory (education) 
and specialisation (subject-/phase-specific) courses to proceed in isolation from one another, albeit with a policy-compliant 'knowledge mix'. The extent to which university-based coursework ensures that the potential connections happen in practice requires a kind of programmatic leadership and coordination that moves well beyond the day-to-day management of logistics. Teacher educators who teach on the programme need themselves to understand the logic of the curriculum design, the rationale for knowledge selection and sequencing decisions, and the contribution that the courses they teach need to play in supporting students' developing teaching practices. It is only with this kind of broadened perspective that teacher educators can collaborate with one another across different courses and plan for making conceptual connections visible to the students they teach.

\section{Implications of this study for higher education}

Academic degrees (such as a BA, BSc or BCom) generally consist of a sequence of courses that induct students into 'conscious reflection on and systematic investigation of established knowledge' in a discipline (Slonimsky and Shalem 2006, 46). Students may choose from a range of subjects, each which develops their conceptual understanding through a systematic sequence of modules. In contrast, university-based programmes that prepare students for professional practices need not only consider the conceptual development in each stream of courses, but curriculum designers also need to consider the links that can (and should) be made between streams of courses that run concurrently. Studying each course as a stand-alone entity does not necessarily mean that students will themselves make the links needed for the development of a coherent professional practice. University lecturers who teach courses in academic degrees can focus their attention on the knowledge selection and sequencing in their courses, however those who teach courses in professional practice need to consider an extra dimension: what their course contributes to the development of the ability of students to engage in that professional practice. For this, they need to consider not only the knowledge selection and sequencing within their modules, but also the way in which the concepts they introduce and develop have links with other courses in the programme.

\section{CONCLUSION}

University-based coursework supports the development of professional practice by introducing students to theoretical ideas that cannot be acquired by classroom experience, or that could potentially be acquired by experience but that are considered too important to be contingent knowledge. The analysis of the compulsory coursework offered in ITE programmes offered by 
five universities shows how each of the four essential elements of all teaching interactions (namely the knowledge to be taught and learnt, the learners, the context and the pedagogic approaches) is an object of study within compulsory coursework offered. However, by its very nature, compulsory coursework in ITE programmes demands a generic approach relevant to all students, and therefore disconnected from students' phase/subject specialisations. Furthermore, theoretical insights are by their nature decontextualised, and therefore potentially powerful over diverse contexts. To support the development of an integrated knowledge-based practice, programme designers need to ensure not only that students develop conceptual understanding of each of the essential elements of that practice, but that they also learn how these elements relate to one another - theoretically, and in relation to the complexity of practice.

Without an understanding of the overall design of the conception of teaching underpinning the curriculum design, teacher educators may miss important opportunities explicitly to draw students' attention to connections where they exist. This, I have argued, unnecessarily undermines the conceptual coherence of the programme. This article has shown that there are many possible links that could be made between concepts in different courses: between the conceptual objects of study, between the compulsory and elective parts of a professional programme, and between university-based coursework and practicum expectations. Making these connections visible to students is essential if their ITE programme is to help them access the internal logic that underpins their developing professional practice. This analysis suggests that these connections require both a strong concept of teaching that informs the logic of curriculum design, and strong academic leadership that seeks to develop a shared understanding of the logic of programme design among those who teach it.

\section{NOTES}

1. 'Learners' is the preferred South African term for pupils, or students who are still at school.

2. From the Latin, meaning 'without which it cannot happen'.

3. As a different paper considers how courses in these ITE programmes work to develop teacher identity and professionalism, this article will focus its attention on the other four elements of teaching derived from the literature.

4. Similar concepts may be included in generically named modules such as Theoretical Frameworks in Education (University C) and Trends in education (University D).

\section{REFERENCES}

Alexander, R. J. 2000. Culture and pedagogy: International comparisons in primary education. Oxford: Blackwell.

Cochran-Smith, M. and S. Lytle. 1999. Relationships of knowledge and practice: Teacher learning in communities. In Review of research in education, 249-305. American Educational Research Association. 
Council on Higher Education. 2010. Report on the National Review of Academic and Professional Programmes in Education. Pretoria.

Darling-Hammond, L. 1997. The right to learn: A blueprint for creating schools that work. San Franscisco: JosseyBass.

Department of Education. 2001. White Paper Six: Special Needs Education - Building an Inclusive Education and Training System. Pretoria: Government Gazette.

Feiman-Nemser, S. 1990. Teacher preparation: Structural and conceptual alternatives. In Handbook of research in teacher education, ed. W. R. Houston, M. Huberman and J. Sikula, 212-233. New York: MacMillan.

Flores, M. 2006. Being a novice teacher in two different settings: Struggles, continuities, and discontinuities. Teachers College Record 108(10): 2021-2052.

Guile, D. 2014. Professional knowledge and professional practice as continuous recontextualisation: A social practice perspective. In Knowledge, expertise and the professions, ed. J. Muller and M. Young, 78-92. London: Routledge.

Hammerness, K., L. Darling-Hammond, J. Bransford, D. Berliner, M. Cochran-Smith, M. McDonald and K. M. Zeichner. 2005. How teachers learn and develop. In Preparing teachers for a changing world: What teachers should learn and be able to do, ed. L. Darling-Hammond and J. Bransford, 358-389. San Francisco: Jossey-Bass.

Hirst, P. H. and W. Carr. 2005. Philosophy and education: A symposuim. Journal of Philosophy of Education 39(4): 615-632.

Hoban, G. F. 2005. Developing a multi-linked conceptual framework for teacher education design. In The missing links in teacher education design, ed. G. F. Hoban, 1-17. Springer.

Joram, E. and A. J. Gabriele. 1998. Preservice teachers' prior beliefs: Transforming obstacles into opportunities. Teaching and Teacher Education 14(2): 175-191.

Korthagen, F. 2004. In search of the essence of a good teacher: Towards a more holistic approach in teacher education. Teaching and Teacher Education 20: 77-97.

Levine, A. 2006. Educating school teachers. Washington: Education Schools Project.

Loughran, J., A. Berry and P. Mulhall. 2006. Understanding and developing science teachers' pedagogical content knowledge. Rotterdam: Sense Publishers.

Morrow, W. 2007. Learning to teach in South Africa. Pretoria: HSRC Press.

Reeves, C. and M. Robinson. 2014. Assumptions underpinning the conceptualisation of professional learning in teacher education. South African Journal of Higher Education 28(1): 236-253.

Rusznyak, L. and C. Bertram. 2015. Knowledge and judgement for assessing student teaching: A crossinstitutional analysis of teaching practicum assessment instruments. Journal of Education 60: 3161.

Rusznyak, L. and E. Walton. 2014. Using metaphors to gain insights into South African student teachers' initial and developing conceptions of being a teacher. Education as Change 18(2): 1-21.

Samuel, M. 2008. Accountability to whom? For what? Teacher identity and the Force Field Model of teacher development. Perspectives in Education 26(2): 3-16.

Samuel, M. 2010. Searching for a 'pedagogy of hope': Teacher education and the social sciences. Perspectives in Education 28(1): 5-23.

Shalem, Y. and L. Slonimsky. 1999. Can we close the gap? Criteria and obligation in teacher education. Journal of Education 24: 5-30.

Shalem, Y. 2014. What binds professional judgement? The case of teaching. In Knowledge, expertise and the professions, ed. M. Young and J. Muller. London: Taylor and Francis.

Shay, S. 2013. Conceptualizing curriculum differentiation in higher education: A sociology of knowledge point of view. British Journal of Sociology of Education 34(4): 563-582. 
Slonimsky, L. and Y. Shalem. 2006. Pedagogic responsiveness for academic depth. Journal of Education 40: 35-58.

Winch, C. 2014. Know-how and knowledge in the professional curriculum In Knowledge, expertise and the professions, ed. M. Young and J. Muller. London and New York: Routledge. 